\title{
Shrinking gender wage gaps in the Brazilian labor market: an application of the APC approach
}

Diminuição do hiato salarial entre gêneros no mercado de trabalho brasileiro: uma aplicação da abordagem IPC

Samantha Haussmann

Universidade Federal de Minas Gerais

André Braz Golgher

Universidade Federal de Minas Gerais

\begin{abstract}
Labor market literature attests that men tend to earn more than women in similar occupations in Brazil and elsewhere. However, some recent trends that have occurred in Brazil promote the narrowing of gender gaps in the labor market. This paper analyzes this issue empirically with the use of PNADs, Mincerian wage equations, and a hierarchical model based on the Age-PeriodCohort approach. We observed that gender wage gaps were shrinking and, although there might still be an unexplained advantage for men in the labor market, the evolution of women's endowments for the labor market and the decrease in labor market segregation significantly compensated for this difference. Due to these trends, after controlling for cohort differences, we observed non-significant gender wage gaps in some models.
\end{abstract}

\section{Keywords}

labor market; gender; Brazil.

JEL Codes J31; J70.

\section{Resumo}

Como comumente apontado pela literatura sobre as diferenças salariais por sexo, em geral, homens recebem mais que mulheres em ocupações similares. Entretanto, algumas tendências atuais no Brasil mostram que os hiatos no mercado de trabalho entre os gêneros estão diminuindo em diversos aspectos. Esse artigo analisa essa questão empiricamente fazendo uso de PNADs, equações Mincerianas e modelos hierárquicos baseados na abordagem Idade-Período-Coorte. Uma das conclusões principais do artigo é que apesar das mulheres terem salários menores que os homens para ocupações, locais de residência e niveis educacionais similares, os atributos femininos associados ao mercado de trabalho e a diminuição na segregação ocupacional parcialmente compensam essa vantagem não explicada dos homens. Além disso, depois de controlados os efeitos por coorte, observa-se uma convergência entre os gêneros e verifica-se que muitos dos hiatos são não significativos.

\section{Palavras-chave}

mercado de trabalho; gênero; Brasil.

Códigos JEL J31; J70. 


\section{Introduction}

Labor market literature attests that men tend to earn more than women in similar occupations in Brazil and elsewhere (Camargo; Serrano, 1983; Barros et al., 2001; Arabsheibani; Carneiro; Henley, 2003; Leme; Wajnman, 2000; Madalozzo, 2010; Nopo, 2012a,b; Weichselbaumer; Winter-Ebmer, 2003). The concentration of women in low-paid occupations and the existence of gender wage gaps have several plausible explanations, some of which we describe below.

In traditional societies, it is more common for women than for men to withdraw temporarily from the labor market or to choose jobs with flexible schedules and/or with fewer working hours. Women's main reasons for doing so arise from housework and childcare responsibilities. Consequently, women accumulate less labor market experience than men do, and women tend to invest less in education and on-the-job training, as they anticipate shorter and more discontinuous work lives (Blau; Khan, 2000; Madalozzo, 2010).

Other factors, such as labor legislation, maternity leave and pregnancy protection, may increase women's labor costs, impact negatively on females' wages (Madalozzo, 2010), and decrease the employability of women (Blau; Khan, 2000). Occupational segregation and discrimination against women might also be important in determining relative wages (Blau; Khan, 2000; Oliveira, 1997; Leme; Wajnman, 2000; Ñopo, 2012a,b)

However, some recent trends might change this perspective on females' disadvantages in the labor market. For instance, there was an increase in the participation of females in the labor market, while the participation of men was, at most, stable in recent decades (Juhn; Potter, 2006; Wajman; Rios-Neto, 2000). This indicates that the labor market is becoming a more female locus, with a relative increase in females' experience vis-à-vis that of males, a feature that might positively affect many women's outcomes in traditional labor markets.

Moreover, there was a recent remarkable decrease in fertility rates in Brazil. Nowadays, fertility levels in this country are below replacement level, and fertility rates are still decreasing (Potter et al., 2010). Women tend to be less productive than men are, and consequently earn less, because during their reproductive life they tend to interrupt their careers, temporarily withdrawing from the labor market. Thus the decrease in the burden of raising children due to this fertility decline, mostly affecting women, has a direct 
impact on females' available time to invest in the labor market, increasing women's competiveness. In addition, lower fertility rates reduce the cost of female labor by reducing the demand for maternity leave (Madalozzo, 2010).

However, women tend to be more household-focused than men and are still responsible for most domestic tasks. For instance, Bruschini (2006) analyzed the amount of time spent by males and females on domestic chores in Brazil, in 2002. She concluded that the time spent by women was much greater than that spent by men. However, household chores are becoming lighter and more evenly distributed among the sexes (Juhn; Potter, 2006), and consequently, women's time availability potentially employed in the labor market increased (Madalozzo, 2010), especially among more qualified females, as differences between sexes decreased for more educated individuals (Bruschini, 2006).

In addition, divorce rates increased and, as divorced women tend to participate more in the labor market, this promoted an increase in females' labor market participation (Fernández; Wong, 2011). Furthermore, the end of the widely held societal understanding of marriage as a lifelong investment (Amato; Rogers, 1999) relatively increases the value of women's labor market investments in formal education and on-the-job training, resulting in higher productivity and wages vis-à-vis men.

Moreover, the service sector's increasing share of the economy, which created more labor demand in occupations well suited to women, helped females to gain access to many better-paid types of occupations (Juhn; Potter, 2006). Traditional societies relied on many agricultural and manual jobs which required a high degree of physical strength. In contrast, most current jobs are less physically demanding, but they require other attributes, such as patience and dexterity, in which females do not have disadvantages when compared to men (Blau; Kahn, 2000).

In Brazil, females tend to have higher schooling levels than men, and differences are increasing (Whinter; Golgher, 2010). This might positively influence women's labor market participation, as education and participation are positively correlated. Besides, this surely will promote an increase in the proportion of female participation in qualified jobs, decreasing occupational segregation (Blau; Kahn, 2000; Madalozzo, 2010).

Finally, greater opportunity in the labor market for women might have an impact on many of the phenomena described above, as more educated working women tend, for instance, to have fewer children and greater bar- 
gaining power (Jensen, 2012). Due to circular causality, these features might create virtuous cycles between labor market participation and social norms, promoting further advances in women's relative labor market positions.

Due to these trends, and as emphasized by Juhn and Potter (2006), women's choices regarding human capital investments, marriage and fertility shape females' values and roles in the labor market and in society, promoting changes over their life course. Moreover, as young women reach working age, they will probably make pro-labor market decisions and lifelong career plans more frequently than older cohorts did. Because of all these trends, females' labor market participation rapidly improved both quantitatively and qualitatively in Brazil relative to men's participation (Barros, 2001): wage and labor market participation gaps and labor market segregation decreased, and a convergence between sexes was observed.

In order to clarify the main objective of this paper, we present in Table 1 some hypothetical examples of gender wage gaps and labor market participation by educational level and occupational prestige. The table presents four situations, from time 1 to time 4, which can be viewed as a path from males' to females' supremacy in the labor market. In each situation, occupations are classified in three categories of educational level and two of prestige. At each time, there are ten men and ten women in the labor market, who are distributed in each of the six possibilities of education and prestige: the first number is for men and the second for women. For instance, in time 1, one man was classified as having an occupation of high education and high prestige and no women were in this category. At this same time, four men had positions classified as low educational level and high prestige, and three women were in this same category. Moreover, in time 1 , women earned $70 \%$ as much as men in occupations of similar educational level and prestige.

In time 1, men earn more than women within each occupational type, and the distribution among occupational types favors men. In time 2 , the distribution of occupational types does not favor either sex, but men earn more than women within each type. In time 3 , although men continue to earn more than women within each occupational type, the distribution among occupational types now favors women; females are overrepresented in higher levels of education and prestige. In time 4, women earn more than men within each occupational type, and the distribution among occupational types favors women. 
Table 1 Hypothetical examples of gender wage gaps and labor market participation by educational level and occupational prestige.

\begin{tabular}{|c|c|c|c|c|}
\hline & \multicolumn{4}{|r|}{ Time } \\
\hline & 1 & 2 & 3 & 4 \\
\hline & \multicolumn{4}{|c|}{ Occupations by prestige } \\
\hline Occupations by educational level & High & Low & High & Low \\
\hline High & 1.0 & 1.1 & 1.1 & 1.1 \\
\hline Intermediate & 2.1 & 2.3 & 2.2 & 2.2 \\
\hline \multirow[t]{3}{*}{ Low } & 4.3 & 0.2 & 4.4 & 0.0 \\
\hline & \multicolumn{4}{|c|}{ Ratio for women/men wages for the same category } \\
\hline & $70 \%$ & $80 \%$ & $90 \%$ & $105 \%$ \\
\hline
\end{tabular}

This paper analyzed labor market gaps between sexes in Brazil taking into account that educational levels and labor market segregation varied recently. In the empirical analysis, we used the National Household Sample Surveys (in Portuguese: PNAD - Pesquisa Nacional por Amostra de Domicílios) of 1992, 1997, 2002, 2007 and 2012. Concerning our econometric strategy, we initially estimated Mincerian wage equations using OLS with different sets of controls. The objective is to analyze gender wage gaps with and without controls associated with education and labor market segregation. We began with the classical analysis of gender wage gaps with many controls, that is, the traditional approach of comparing men and women in similar occupations and educational levels, and then we dropped some of the controls in order to analyze gender wage gaps taking into account that educational levels and labor market segregation varied over the period.

During the studied period, expectations about women's roles in society radically changed (Juhn; Potter, 2006). In order to apprehend the age, period and cohort effects of labor market trends and evolution, we used a hierarchical model based on Age-Period-Cohort approach. The objective is to focus the analyses on cohorts, as cross-section analysis might be misleading (Leme; Wajnman, 2000; Wajnman; Rios-Neto, 2000). To the best of our knowledge, this is the first attempt to analyze gender wage gaps in the Brazilian labor market using this methodology.

Besides this introduction, this paper is divided as follows. The second section presents a brief literature review of gender labor market gaps. The third discusses the APC approach, the theoretical background of the pa- 
per. The fourth presents some descriptive statistics regarding labor market trends in Brazil, giving an overall perspective on labor market evolution with emphasis on sex differentials. The fifth section describes the applied methodology. Initially we present the databases, then we discuss the Mincerian equations and the variables used in the models, and, after this, we present the hierarchical model. The sixth section presents the results of the econometric models. The last section concludes the paper.

\section{Literature review}

This section presents a selection of papers that discussed gender gaps in the labor market. The objective is to give an overall description of the field, giving special attention to the Brazilian reality.

Many studies observed a tendency toward shrinking gender wage gaps in different settings (For instance, Blau; Kahn, 2000; Brown; Corcoran, 1996; Weichselbaumer; Winter-Ebmer, 2003). Blau and Kahn (2000) verified a shrinking gender wage gap in the U.S.; this trend was more rapid in the U.S. until the 1990s than it was in many other European countries. According to these authors, one of the reasons for these trends is that greater numbers of women are entering better-paid occupations that were traditionally dominated by men. Moreover, these authors observed a decrease in the size of the unexplained gender gap, possibly due to an upgrading of women's unobservable skills and/or lower levels of discrimination.

Similarly, Brown and Corcoran (1996) analyzed gender wage gaps in the U.S. and observed that one of the reasons for the closing gender gaps was the increase in female participation in better-paid occupations that were traditionally dominated by men. They noted that differences in the proportion of college graduates by field accounted for a significant part of the gender earnings gap, as women were overrepresented in careers with lower wages.

Weichselbaumer and Winter-Ebmer (2003) performed a meta-analysis of the international gender wage gap using 260 published papers covering 63 countries during the period of the 1960s - 1990s. They observed a remarkable decrease in the wage gap between men and women, mostly due to an equalization of productive characteristics. They also compared many different methods of analysis, in particular the use of a dummy re- 
presenting the sexes in econometric models, and the traditional use of the Oaxaca-Blinder decomposition, and results did not differ consistently for gender wage gaps. Moreover, they noted that the gender wage gap was smaller if only a sample of new entrants in the labor market was investigated or if only high-prestige jobs were analyzed.

In a similar vein, Manning and Swaffield (2008) emphasized that cross-section data confound true life-cycle effects and cohort effects. They observed that the gender pay gap between sexes in the UK was approximately zero upon entry into the labor market, but it grew afterwards. They explored three main hypotheses to explain why the gap between men and women grew over time. Human capital factors - gender differences in accumulated work experience, investments in human capital and domestic commitments - explained approximately $50 \%$ of the gap. The job-shopping hypothesis, which states that an important part of early career wage growth is associated with moving from worse to better-paying jobs, explained around $6 \%$ of the gap. Psychological differences between men's and women's attitudes toward risk-taking, competition, self-esteem, and selflessness at the age when they enter the labor market accounted for up to $20 \%$ of the gap.

These two cited studies described the importance of a life course perspective while analyzing labor market outcomes. Using a similar standpoint, Blau and Kahn (2000), Bailey, Hershbein and Miller (2012) and Fernández and Wong (2011) analyzed gender wage gaps in the U.S. with a cohort perspective. The first authors observed that younger cohorts were faring better in the labor market than older ones. Bailey, Hershbein and Miller (2012) noted that younger cohorts narrowed the gender gaps in educational attainment, labor market experience, and employment in traditional male occupations. As highlighted in the introduction of this paper, Bailey, Hershbein and Miller (2012) and Fernández and Wong (2011) emphasized that there are many factors associated with these trends. These factors include skill biased technological changes in the workplace and in the household, changes in ideals about women's roles and expectations in the workplace, increases in first marriage age, decreases in childcare costs, and increases in enforcement of anti-discrimination legislation. The "Pill" and increasing divorce rates were also important potential factors in these shrinking wage gaps. For instance, younger unmarried women improved their access to contraception during a period that is critical to their ca- 
reer investments, decreasing labor market gaps (Bailey; Hershbein; Miller, 2012). Fernández and Wong (2011) observed that gender gaps in labor participation fell remarkably and that changes in divorce probabilities alone accounted for more than half of these trends.

Arulampalam, Booth and Bryan (2007) emphasized that, although gender wage gaps have been widely studied, as in the studies described above, it was only relatively recently that analysis has been performed across the wage distribution, which overcomes some of the limitations of the usual methodology. In this vein, García, Hernández and López-Nicolás (2001) used quantile regressions (OR) to analyze gender wage differences in Spain across the wage distribution. They observed that gender wage gaps were greater for the highest quantiles, although differences between quantiles were not great and standard errors were large. Arulampalam, Booth and Bryan (2007) applied the OR approach to European data. They defined that a glass ceiling effect existed if the $90^{\text {th }}$ percentile wage gap was larger than the wage gaps in other parts of the wage distribution by at least two percentage points. They observed that most countries showed this effect. Similarly, Albrecht, Bjorklund and Vroman (2001) analyzed data for Sweden and observed a glass ceiling effect in the 1990's, but not in prior decades. Rica, Dolado and Llorens (2008) used a similar approach applied to the Spanish data, and observed this pattern for highly educated workers, but not for less-educated ones.

Some other authors discussed data from Latin America and/or Brazil. Nopo (2012a) analyzed the evolution of gender earning gaps in Latin America. The author points out that, although women are overrepresented in low-paid occupations, the general distribution of observable characteristics favors women when compared to men, indicating that the unexplained part of the gender earning gap is remarkable. Nevertheless, the author observed that both explained and unexplained gender gaps decreased recently.

Following Arabsheibani, Carneiro and Henley (2003), the first analysis of pay gaps in Brazil was done in the mid-eighties by Camargo and Serrano (1983). These last authors analyzed industrial jobs using the RAIS database and observed the existence of gender wage gaps in favor of men. Moreover, they noted that the main determinant of wages differed by sex: for men it was the structure of the industrial sector and for women it was educational level. 
After this first study regarding gender labor market gaps in Brazil, many others followed. For instance, Leme and Wajnman (2000) observed a decrease in gender wage gaps using PNADs and the Oaxaca decomposition. They observed that the increase in women's educational levels, associated with relatively greater returns for these attributes and a decrease in discrimination against women, had a positive impact on females' wages vis-à-vis males'. In addition, younger cohorts obtained greater returns for their human capital investments, suggesting further positive impacts on females' wages in the long run.

Barros et al (2001) emphasized that, although men still tended to earn more and to work in greater proportion and for more hours than women, females' labor market participation rapidly improved both quantitatively and qualitatively. Moreover, they observed that, while there was a clear labor market segregation by sex, traditional female occupations showed similar wages to those in which men had historically predominated.

Arabsheibani, Carneiro and Henley (2003) also analyzed gender wage differentials in Brazil. They used PNADs and the Juhn, Murphy and Pierce (JMP) decomposition. The authors observed that gender wage gaps decreased mostly due to lower levels of discrimination against women. Moreover, they emphasized that some other trends had a positive impact on narrowing these gaps. For instance, the positive evolution of females' observable earning-improving endowments, such as human capital level, and also of non-observables, such as effort, relatively increased women's wages vis-à-vis men's.

Silva, Carvalho and Neri (2006) analyzed wage differentials between gender and race using the 2003 PNAD and the Oaxaca and Heckman procedures. They concluded that white men earned more than other groups, in part due to discrimination.

Madalazzo (2010) also observed narrowing gender wage gaps in Brazil from 1978 to 2007. She observed that labor market segregation decreased for careers traditionally dominated by men, while women continue to dominate those occupations considered female. According to the author, given that the first type of occupation tends to pay better wages, this fact positively influenced the convergence of wages between the sexes.

Similarly, Nopo (2012b) analyzed the composition and evolution of gender earnings gaps in Brazil using PNADs. As in the other cited studies, the author observed that overall gender wage gaps decreased in Brazil, and that 
the largest proportion of variability was unexplained; the unexplained portion is normally linked to discrimination in the labor market. He observed that women would earn more than men if the unexplained portion of wage gaps did not exist, as women had better earning-improving endowments. The author also verified that gender earning gaps increased with age for young cohorts, and that younger cohorts showed smaller gender gaps.

Salardi (2014) analyzed the evolution of gender occupational segregation in the Brazilian labor market between 1987 and 2006. She observed that gender segregation has fallen during this period, mostly due to a declining concentration by gender within individual occupations.

All these studies that analyzed the Brazilian reality pointed to a convergence in labor market outcomes by sex. The current paper is similar in many aspects to those discussed above; however, besides being a more updated study, it is founded on a different theoretical perspective and on a distinct methodology, which are based on the Age-Period-Cohort (APC) approach. This approach is described in the next section.

\section{The Age-Period-Cohort (APC) approach}

This paper develops the exercise of placing labor market outcomes in a life course perspective, using as theoretical background the APC approach. In this approach, age, period, and cohort effects are analyzed separately in order to disentangle their distinct contributions, as briefly described below. For a more detailed discussion see Mason and Smith (1985), Yang, Fu and Land (2004), Yang and Land (2008), Yang et al. (2008) and Yang (2008, 2011).

When changes that take place in a society affect a specific age group (or groups) most strongly, the result is an age effect, aging-related developmental changes that occur in life. In this case, one would observe that certain age groups, regardless of their cohort or period, share the same characteristics or face the same phenomena. Puberty is a classic example of an age effect. Another example of this could be the probability of older people being more satisfied with life than youngsters.

When changes occur in all age groups at the same time, this configures a period effect, which "reflects changes in social, historical and epidemiological conditions that are unique to a time period that affect all living conditions regardless of age or life stage" (Yang, 2011, p. 18). The econo- 
mic crisis of 1929 and the terrorist attacks of 2001 in the United States are examples of period effects that are likely to affect the society in which they occur as a whole.

Finally, cohort effects refer to individuals who share specific experiences, such as being born in the same year or entering a university in the same period. According to Ryder (1965), birth cohorts represent the effect of formative experience, shaped not only by life conditions from the moment of birth but also by a continuous and shared exposure to historical and social factors that might affect living conditions throughout life, thus making the specific group unique. For instance, individuals of specific cohorts might trust others less than other cohorts, independently of age or period effects.

The APC approach can be applied by different methods. Ideally, one would prefer to work with databases that follow the same individual over time. However, in the absence of longitudinal data to investigate long-term changes in Brazil, we built cohorts using five different PNADs. As described in the methodological section, recently developed statistical tools transform cross-sectional data, such as those provided by PNADs, into well-grounded synthetic cohorts that mimic true birth cohorts (Yang, 2008).

\section{Empirical strategy}

In this section, we present the methodology in three brief subsections. The first one describes the databases, the second, the Mincerian models and the variables, and the last, the hierarchical model based on APC approach.

\subsection{Database}

This paper used the National Household Sample Survey (PNAD in Portuguese), which is an annual survey that has socioeconomic and demographic information about the Brazilian population and is nationally representative. Moreover, the survey has complementary questionnaires with questions associated with fertility, health and other subjects. This database is extensively used to analyze socioeconomic conditions in Brazil, including gender gaps in the labor market (For instance, Leme; Wajnman, 2000; Arabsheibani; Carneiro; Henley, 2003; Madalozzo, 2010; Ñopo, 2012b). 
We used the databases from the years of 1992, 1997, 2002, 2007 and 2012. The last one was the most recent available at the time of this research. The others come in five-year intervals so we could easily build cohorts with the databases. The objective was to have enough time span to comprehend the recent evolution of the Brazilian labor market.

Given the study's objective of analyzing labor market outcomes, we selected individuals from 20 to 69 years old with positive income. Our final sample sizes in the five mentioned years were respectively 102096 , 116126, 136907, 152764 and 145050.

In order to build the cohorts, we initially selected women between the ages of 20 and 54 . The upper limit was selected because older women show a much greater propensity to retire, so the women remaining active in the labor market would be highly self-selected. Then we classified the individuals into five-year age groups. For some cohorts, we did not have the data for all years. Those cohorts were discarded from some of the analysis. Hence, we obtained three cohorts with data in all five PNADs. The youngest cohort was 20 to 24 years old in 1992 and, consequently, 40 to 44 years old in 2012 . The other cohorts with complete data were respectively 5 and 10 years older. Thus, the oldest cohort with data in all five PNADs was 30 to 34 years old in 1992 and, consequently, 50 to 54 in the end of the period. We also defined two other cohorts which did not have data for all years: those aged 10 to 14 and 15 to 19 in 1992 .

\subsection{Mincerian models and variables}

The Mincerian wage equations are commonly used to analyze the relationship between salaries and other variables, such as sex, age and race (Resende; Wyllie, 2006; Madalazzo, 2010). This type of model is extensively used in many applications and settings. For instance, Sachsida, Loureiro and Mendonça (2004) used this econometric model to analyze Brazil and Trostel, Walker and Woolley (2002) used it do study other countries. For an overview of Mincerian equations see Heckman, Lochner and Todd (2003). For a comparison of this method with other approaches see Weichselbaumer and Winter-Ebmer (2003).

The expression below represents this equation as applied in this paper. The model was estimated by OLS with Stata. The selected expla- 
natory variables are commonly used in Mincerian models and detailed afterwards:

$$
\begin{aligned}
& \ln (Y)=\beta_{0}+\beta_{1} \text { Male }+\beta_{2} \text { Ethnic }+\beta_{3} \text { Age }+\beta_{4} \text { Age }{ }^{2}+\beta_{5-7} \text { Household }+ \\
& +\beta_{8-11} \text { Schooling }+\beta_{12-15} \text { Occupational }+\beta_{16-21} \text { Geographical }+\varepsilon,
\end{aligned}
$$

where $Y$ is hourlywage, $\beta_{S}$ are the estimated coefficients, the explanatory variables are briefly named above, and $\varepsilon$ is the normally distributed stochastic error.

The dependent variable is the logarithm of hourlywage, as commonly used in similar analysis (For instance, see Khamis, 2008).

Many studies analyze gender wage gaps using a dummy variable for sex. Another widespread applied methodology is the use of separate equations for each sex and a subsequent decomposition by Oaxaca-Blinder or other methods (Weichselbaumer; Winter-Ebmer, 2003). We chose to use the dummy variable approach (1 - Male, 0 - Female) as an initial study that is complemented by the hierarchical models and the APC approach.

Some variables are commonly used as controls in Mincerian equations (See Heckman, Lochner and Todd (2003) for a general discussion). The models used in this paper include a dummy for ethnic group (1 - White/ Asian, 0 - Black/Brown/Indigenous), as differences are envisaged between these groups. We expect a positive coefficient, as observed in Arabsheibani, Carneiro and Henley, 2003.

Age is proxy for experience and is represented by a continuous variable. Age-squared is also included in the model in order to account for non-linearities. Experience is also measured using as proxy the result of age 6 - number of years in school. However, we believe that many Brazilians acquire working experience while in school; therefore we did not account for the number of years in school while building our explanatory variable. We expect a positive coefficient for the first and a negative for the second, as wages tend to increase more quickly in the beginning of professional life, as observed in Madalozzo (2010).

Another factor that might influence earnings is the relationship of the individuals in the household. For instance, it is expected that household heads earn more than other individuals in the household do, as they tend to be more focused on labor market outcomes. This tendency is more pronounced because the head is defined by the individual's share in 
household income. Thus, the models include three dummies for spouse, for children and for other members in the household, with the reference being the household head. Negative coefficients for all three dummies are expected.

It is well known that one of the main determinants of wage inequalities is educational level. Hence, we included four dummies for educational level. We chose to use dummies due to non-linearities and varying marginal returns to education, as in Madalozzo (2010). The dummies represent those who had 4 to 7 years of formal education (upper elementary level), 8 to 10 years of education (complete elementary level or incomplete high school), 11 (high school diploma), or 12 and more (at least some tertiary level). The category 0 to 3 (no education or lower elementary level) is the reference. We expect positive signs for all of them with increasing magnitude.

Four dummies representing the type of occupation of the worker were also included in the model, as men and women tend to be segregated in the labor market (Madalozzo, 2010; Oliveira, 1997). The categories are: worker with formal documents, public worker, self-employed and employer. The reference is informal workers. We expect positive coefficients for all but the self-employed. This last group is very heterogeneous (Khamis, 2008) and we do not have a prior expectation.

There are at least two other variables in the database that could be used to further classify occupation types, which are occupational groups and sector of activity. The focus of the paper is to analyze wage gaps without controlling for distributional effects among occupational groups and sector of activity. Therefore, we did not include further variables for occupation types.

Given that Brazil is highly spatially heterogeneous, we also included some geographical variables, as in Arabsheibani, Carneiro and Henley (2003) and in Madalozzo (2010). The first is a dummy for urban areas and another for metropolitan areas. Positive coefficients are expected for both, as wages tend to be higher in these regions than in rural and non-metropolitan areas. Moreover, we included four dummies associated with the macroregions in Brazil: North, Northeast, South and Central-West. The Southeast region is the reference. We expect a negative coefficient for all dummies, as this last region is in many aspects the most developed in Brazil and tends to have the highest wages.

Interactions were initially included in the models, but results were poor and we dropped them from the final models. 
The proposed model does not differ much from other studies of Brazilian data and there is no innovation in it. The empirical strategy, however, includes some new perspectives. We estimated the models separately by year and for particular cohorts and they are the basis for further discussions using hierarchical models. We describe this model in the next section.

\subsection{Hierarchical model and the age-period-cohort approach}

Mincerian models enable the analysis of age, period and/or cohort effects; however, this approach has some limitations, as these three parameters have confounding aspects if used together in the same regression (Yang; Fu; Land, 2004). That happens because, by knowing one person's age and the year of the interview, it is possible to learn his/her year of birth (or cohort). Because of the linear dependency among age, period, and cohort, models using the APC approach might present problems of identification, which may make the assessment of the age, period, and/or cohort effects troublesome (Yang, 2011).

How can one disentangle the effects of age, period and cohort? In our analysis, we applied a hierarchical model based on the APC approach. In many aspects, the first level of the model resembles the Mincerian equations discussed in the previous subsection and the variables are mostly the same. Given the results of the descriptive section and of the Mincerian models, and due to the expected variability in results for the different cohorts, each cohort was analyzed separately. Notice the term $\alpha_{j}$ instead of $\beta_{S}$, as detailed below:

$$
\begin{aligned}
& \ln (Y)=\alpha_{j}+\beta_{1} \text { Male }+\beta_{2} \text { Ethnic }+\beta_{3} \text { Age }+\beta_{4} \text { Age }^{2}+\beta_{5-7} \text { Household }+ \\
& +\beta_{8-11} \text { Schooling }+\beta_{12-15} \text { Occupational }+\beta_{16-21} \text { Geographical }+\varepsilon,
\end{aligned}
$$

Where $j$ represents periods, and other variables have already been defined.

The equation for the second level of the model is the following:

$$
\alpha_{j}=\pi_{0}+\tau_{0 j} \text { Period, }
$$

Where $\pi_{0}$ is the expected mean at the zero values of all levell variables averaged over all periods, and $\tau_{0 j}$ are the coefficients for periods. 
We applied this methodology using the SAS 9.4 statistical package and the GLIMMIX command.

\section{Descriptive statistics}

This section presents descriptive statistics on trends related to the Brazilian labor market and, in some aspects, is similar to Leme and Wajnman (2000), although updated. The objective is to give an overall perspective on labor market evolution with emphasis on sex differentials, having as background the above discussion of age, period and cohort effects.

Figures 1 and 2 compare labor market participation by age, respectively, for males and females. These trends are well known for the Brazilian labor market (Arabsheibani; Carneiro; Henley, 2003; Leme; Wajnman, 2000; Madalozzo, 2010; Salardi, 2014; Wajnman; Rios-Neto, 2000). Many aspects of the trends in Brazil are similar to those in other countries (Juhn; Potter, 2006). Values for males are higher than for females in any given age group, and dynamics differ between sexes.

Figure 1 Labor market participation for males in different age groups in different years

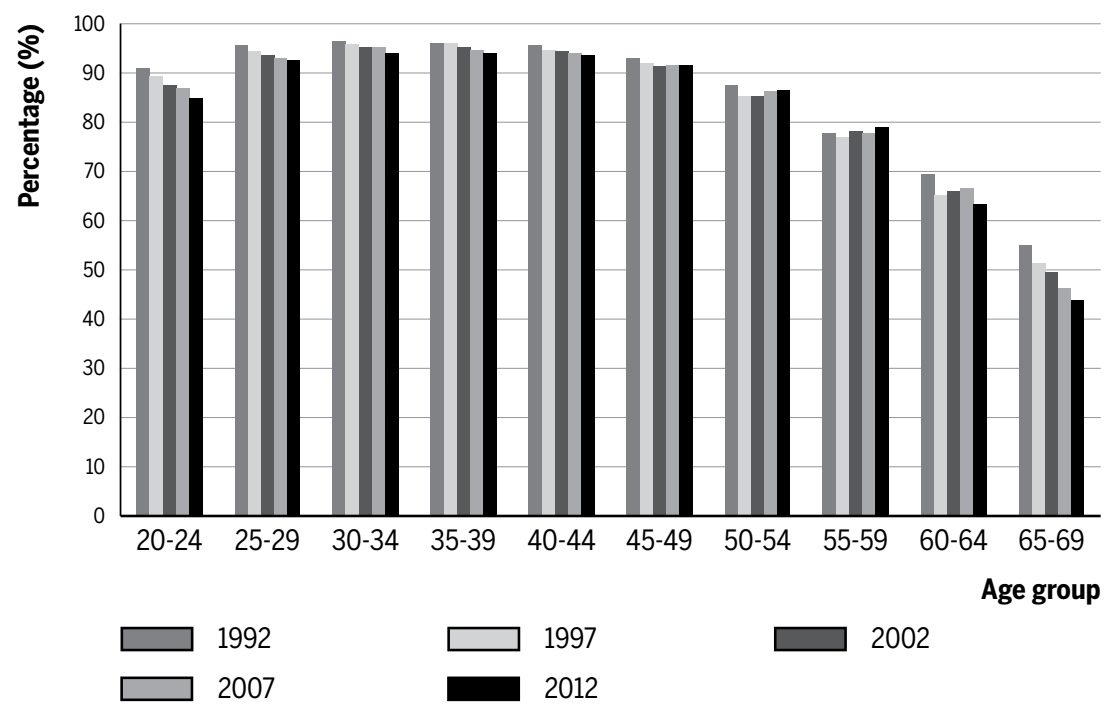

Source: PNAD 1992, 1997, 2002, 2007 and 2012 
Figure 2 Labor market participation for females in different age groups in different years

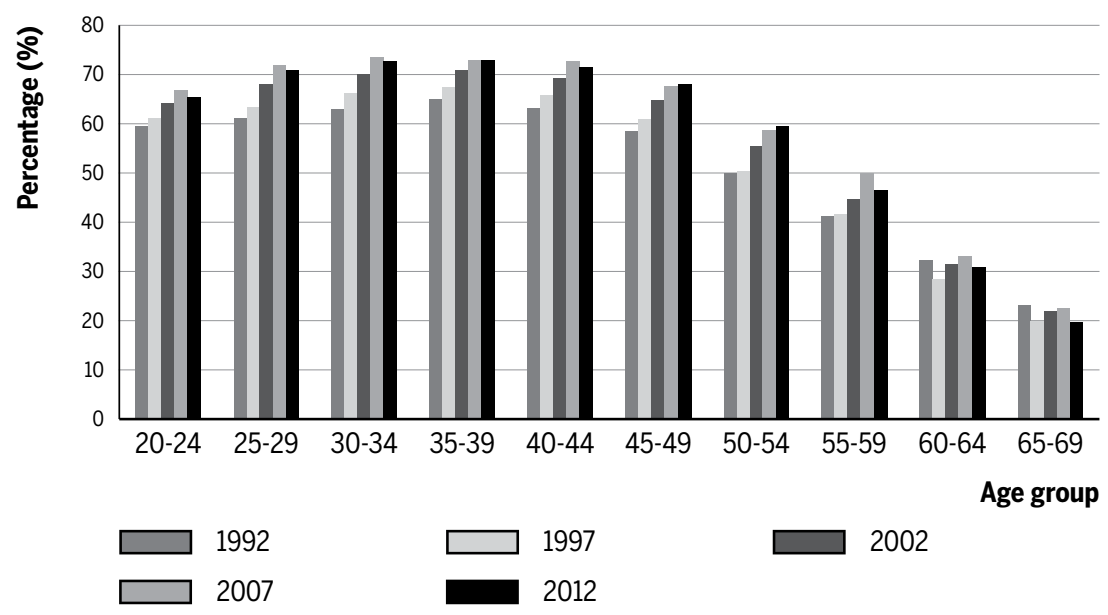

Source: PNAD 1992, 1997, 2002, 2007 and 2012

Male values decreased between 1992 and 2012 in the first two age groups, suggesting that some men are postponing labor market insertion in order to enhance their schooling levels. However, at least one other phenomenon might affect these results. Many young males are simply becoming part of the triple no group: they do not study, do not work and do not look for a job (Camarano; Kanso, 2008). Labor market participation decreased in the last two age groups in the period, possibly due to earlier retirement (Glomm; Jung; Tran, 2009; Queiroz, 2006). For the other age groups, the values were reasonably stable.

For females, labor market participation increased between 1992 and 2012 in all age groups but the last. Nevertheless, values appear to have remained stable since 2007, suggesting that a limit to this increase might have been achieved. Wajnman and Rios-Neto (2000) also observed a similar result and emphasized that female labor market participation will not reach North American levels in the near future. One of the reasons for this suggested limit is the sizable proportion of the female population in Brazil, around $25 \%$, in the triple no group (Golgher, 2010).

Figure 3 shows the sex ratios for labor market participation by age group in different years. Not surprisingly, male workers were the majority in all age groups and years, as described in Figures 1 and 2. Another noticed tendency is that the values are decreasing over the period, indicating the 
relative increase in female participation. Moreover, for each specific year, the numbers remain approximately constant up to a given age - the 40-44 group in 1992 and 1997, 45 - 49 in 2002 and 2007, and 50- 54 in 2012-and then increased. This suggests that women are becoming increasingly active relative to men, especially in older groups.

Figure 3 Sex ratio for labor market participation in different age groups in different years

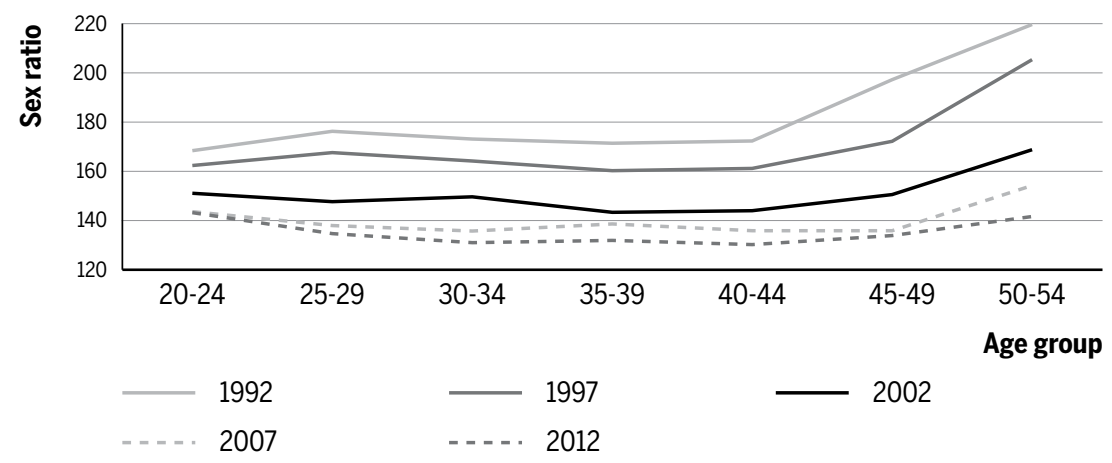

Source: PNAD 1992, 1997, 2002, 2007 and 2012

Figure 4 Sex ratio for labor market participation in different cohorts (by age in 1992) in different years

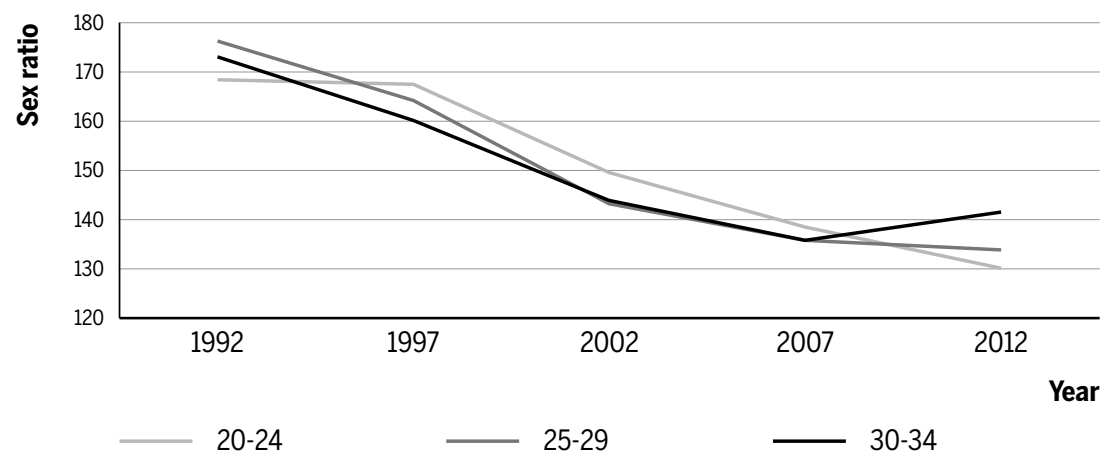

Source: PNAD 1992, 1997, 2002, 2007 and 2012

Figure 4 presents the results for labor market participation by cohort. Leme and Wajnman (2000) emphasized that the use of cohorts may be more effective than describing the data only for periods in order to analyze labor market outcomes. Similarly, Wajnman and Rios-Neto (2000) describe 
the importance of discussing cohorts in labor market analysis. Examples of other studies that addressed labor issues with a cohort perspective are Bailey, Hershbein and Miller (2012), who analyzed the gender wage gap in the U.S., and Fernández and Wong (2011), who described trends in education and labor market participation in the U.S.

Figure 4 shows the results for the three cohorts with data in the five PNADs, those who were aged 20-24, 25-29 or 30-34 in 1992. Notice that there was not much difference between cohorts in each specific year: sex ratios in the labor market decreased from approximately 170 in 1992 to 135 in 2012.

The results of these two last figures indicate that women are becoming increasingly active relative to men, specifically due to period effects, as highlighted by the great difference in Figure 3 and the resemblance between cohorts shown in Figure 4. The period effects reflect changes in social and historical conditions of the period that affect the life of individuals regardless of their age (Yang, 2011). For instance, divorce probabilities increased, technological change occurred in the workplace and in the household, and expectations about women's role changed towards working women, irrespective of age or cohort. Economic crisis may also play a role as, for instance, women's labor participation might increaseas a strategy to complement household income in particular periods. Montali (2003), for instance, discusses, for the Brazilian context, the relationship between economic restructuring and increasing unemployment and new household configurations regarding the labor market.

This descriptive analysis presented in figures 1 to 4 regarding labor participation shows that gender gaps decreased between 1992 and 2012. How much further will they diminish? Given the trends described above, it is likely that gaps will continue to decrease, but the pace of this decrease will slow in the future.

Some other trends in the labor market are also contributing to decreasing gender gaps. For instance, among those who work, men still work for longer hours in all age groups, as shown in Figure 5. However, differences between sexes decreased for all age groups in the period. Notice that differences for younger groups are quite small nowadays.

Figure 6 shows the results for the same cohorts presented in Figure 4. Notice that for the oldest cohort, aged between 30 and 34 in 1992, the ratio decreased as women got older. For the two youngest cohorts the ratio also decreased when they were 30 years and above. On the other hand, for these last 
two cohorts, the ratio increased while women were in their twenties. That is, the age of 30 seems to be a threshold. In all cohorts, the gap in working hours between men and women increased before this age and decreased afterwards. These trends might explain part of the divergence between sexes in wages for early career professionals, as observed by Manning and Swaffield (2008). Related to these results are some aspects associated with motherhood and time allocated to domestic activities (Bailey; Hershbein; Miller, 2012; Bruschini, 2006; Fernández; Wong, 2011; Maume; Sebastian, 2012; Tsang et al., 2003). Moreover, as women tend to study more than men do, they might spend a greater amount of time acquiring formal education, which will positively affect wages in the future. That is, they are postponing earnings.

Figure 5 Ratio of number of hours spent working by men and women by age group in different years

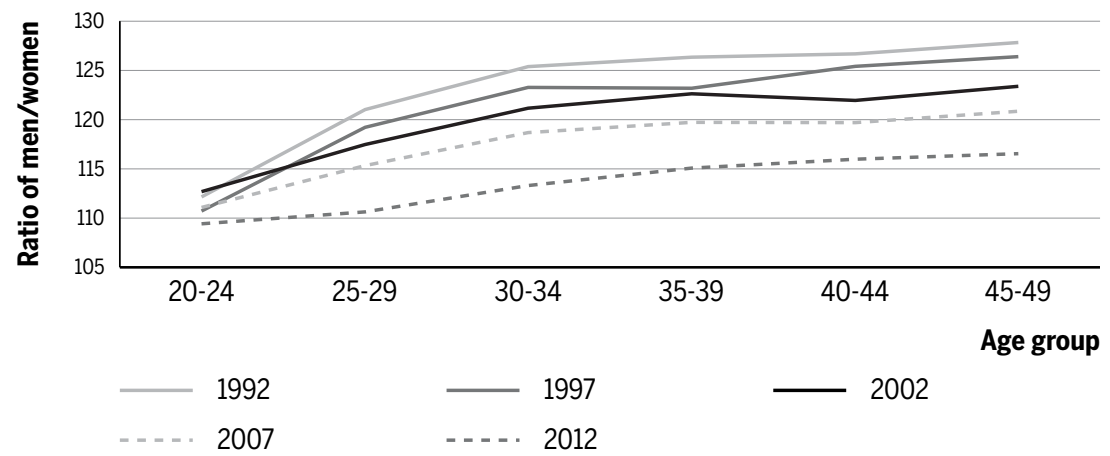

Source: PNAD 1992, 1997, 2002, 2007 and 2012

Figure 6 Ratio of number of hours spent working by men and women, grouped by cohort by age in 1992, in different years

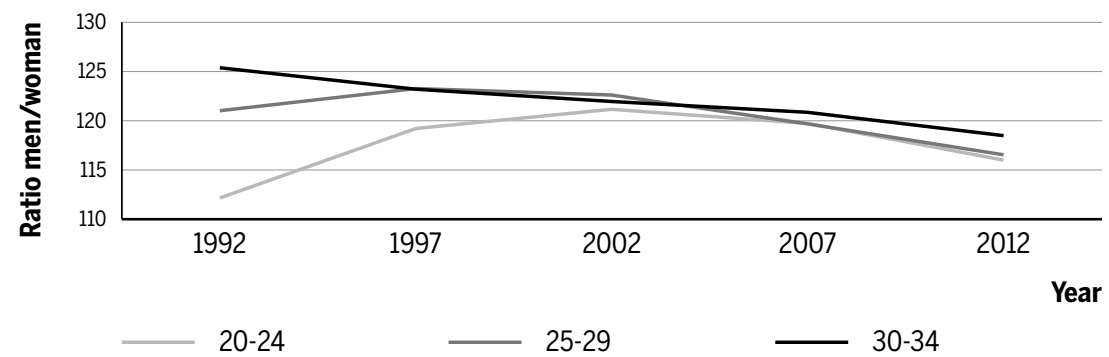


The results presented in Figures 5 and 6 suggest that there is a remarkable period effect for workload gaps. Moreover, they also indicate age and cohort effects for these gaps.

Table 2 shows the evolution of educational attainment for male and female workers in the years 1992, 1997, 2002, 2007 and 2012. In the beginning of the period, men and women had similar distributions among the five schooling categories ( 0 to 3 years of formal education, 4 to 7, 8 to 10, 11 and 12 and over), although females had a slight advantage. In 2012, both genders had remarkably increased their mean levels of education; however, women's educational levels had risen more rapidly than men's, increasing the gender gap.

Table 2 Distribution of workers across schooling levels by sex in different years

\begin{tabular}{|c|c|c|c|c|c|c|}
\hline & Schooling level & 1992 & 1997 & 2002 & 2007 & 2012 \\
\hline \multirow{5}{*}{$\sum^{\frac{\sigma}{\omega}}$} & 0 to 3 & 35.5 & 31.1 & 25.4 & 19.7 & 15.3 \\
\hline & 4 to 7 & 31.9 & 31.8 & 29.8 & 25.6 & 22.3 \\
\hline & 8 to 10 & 12.9 & 14.2 & 15.1 & 16.8 & 16.8 \\
\hline & 11 & 11.2 & 13.2 & 18.9 & 24.7 & 28.8 \\
\hline & 12 and over & 8.5 & 9.7 & 10.8 & 13.2 & 16.8 \\
\hline \multirow{5}{*}{ 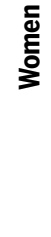 } & 0 to 3 & 26.9 & 21.0 & 15.9 & 11.8 & 8.3 \\
\hline & 4 to 7 & 28.3 & 27.3 & 24.5 & 20.4 & 16.6 \\
\hline & 8 to 10 & 12.9 & 14.5 & 14.7 & 14.9 & 14.2 \\
\hline & 11 & 16.6 & 20.4 & 26.0 & 30.3 & 33.3 \\
\hline & 12 and over & 15.3 & 16.8 & 18.8 & 22.7 & 27.6 \\
\hline
\end{tabular}

Source: PNAD 1992, 1997, 2002, 2007 and 2012

Table 3 shows the distribution of workers, who were students, by sex and age in different years. Naturally, older workers showed smaller proportions of individuals studying, as most had already dropped out of the educational system. However, notice the remarkable difference between the sexes. All the proportions for women are much higher than for men, indicating that overall gaps informal education levels are increasing for those already in the labor market.

So far, the focuses of the analysis were labor market participation, work hours and educational levels. The trends previously presented suggest that gender gaps in the labor market are shrinking, and this might have an impact on earnings by gender. With the increase in women's labor market participation and the increasing educational endowments of women, it 
is natural to expect female empowerment vis-à-vis males in many life dimensions. This may promote a decrease in the relative differences of time allocation for household chores, implicating a further decrease in labor market gender gaps and a relative increase in females' investments in work skills. The final presentation of the descriptive section is on earnings per hour, which complements the preceding discussion.

Table 3 Distribution of workers, who were students, by sex and age in different years

\begin{tabular}{|c|c|c|c|c|c|c|}
\hline & Age & 1992 & 1997 & 2002 & 2007 & 2012 \\
\hline \multirow{4}{*}{$\frac{\bar{\sigma}}{\Sigma}$} & 20 to 24 & 12.5 & 17.9 & 20.4 & 19.4 & 16.8 \\
\hline & 25 to 29 & 4.8 & 7.2 & 10.4 & 10.0 & 9.5 \\
\hline & 30 to 34 & 2.6 & 3.9 & 6.5 & 7.1 & 5.3 \\
\hline & 35 and over & 1.8 & 2.6 & 4.8 & 5.5 & 3.5 \\
\hline \multirow{4}{*}{$\begin{array}{l}\bar{\varpi} \\
\text { छ్ }\end{array}$} & 20 to 24 & 21.4 & 24.1 & 27.8 & 26.5 & 24.6 \\
\hline & 25 to 29 & 8.6 & 11.3 & 15.1 & 15.0 & 13.3 \\
\hline & 30 to 34 & 4.8 & 6.0 & 11.7 & 10.9 & 9.2 \\
\hline & 35 and over & 3.6 & 4.5 & 8.8 & 8.8 & 6.7 \\
\hline
\end{tabular}

Source: PNAD 1992, 1997, 2002, 2007 and 2012

Figure 7 compares hourlywages of men and women at the same schooling level in different years. Men earned more in all schooling levels in all years; however, the gap decreased, especially between 1997 and 2002. Gender gaps increased along with educational level, as suggested by the literature describing glass ceiling effects for income (Albrecht; Bjorklund; Vroman, 2001; Arulampalam; Booth; Bryan, 2007; Rica; Dolado; Llorens, 2008).

Figure 7 Ratio of hourlywages for men and women by educational level in different years

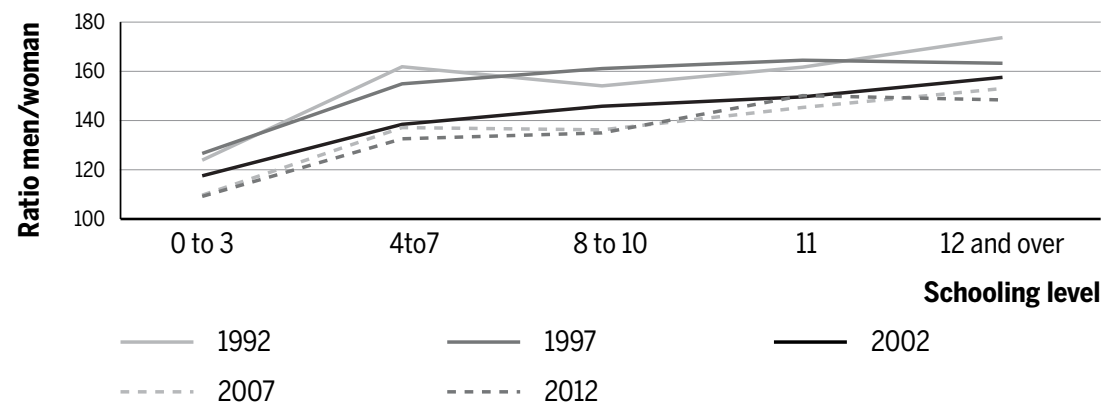


The next figure presents the gender ratios of hourly wages by age group. First, it demonstrates a remarkable age variation, as younger women are much more similar to their male peers than older ones, in accordance with the idea of growing gender gaps amongearly career professionals (Manning; Swaffield, 2008). A period variation is also noticed, as ratios decreased between 1992 and 2002. Values between 2002 and 2012 are approximately the same.

Figure 8 Ratio of hourlywages for men and women by age group in different years

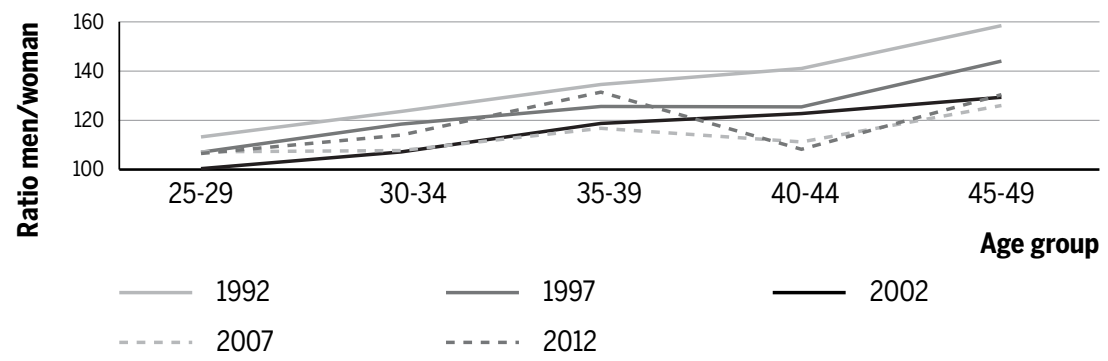

Source: PNAD 1992, 1997, 2002, 2007 and 2012

Figure 9 compares the hourlywages of men and women by cohort in different years. The numbers show that the ratio between men's and women's wages is approximately stable for each cohort, but that younger cohorts show a smaller gap between sexes.

Figure 9 Ratio of hourlywages for men and women by cohort (grouped by age in 1992) in different years

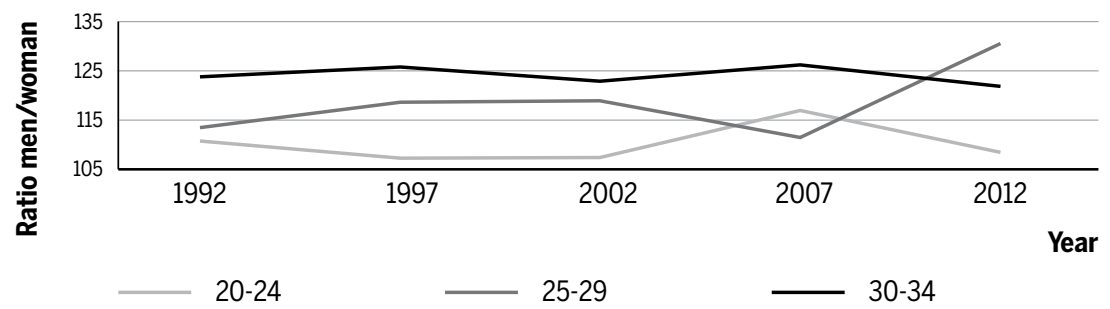

Source: PNAD 1992, 1997, 2002, 2007 and 2012

These two last figures suggested that a cohort effect might exist, as gender wage gaps for younger cohorts are smaller. Figure 8 indicates a variation based on period, but there are confounding factors with cohort and age. 
This section with descriptive statistics clearly indicated that gender gaps in the labor market related to labor market participation, workload, experience and earnings are shrinking; this effect shows most strongly in younger cohorts. Women also have an increasing advantage in educational level. These five trends put together indicate a convergence between the sexes.

We further analyze the data discussed in this section with the use of econometric models in order to better glimpse the convergence between men and women in the labor market. The results are presented in the next section.

\section{Results of the econometric models}

This section presents the results of the econometric models: first those of the Mincerian models and then those of the hierarchical models.

\subsection{Mincerian models}

Table 4 shows the results for the Mincerian equations for each year separately. These models will be the basis for the discussion of all subsequent econometric models. All variables were significant at $5 \%$.

Most results were as expected. White individuals and those who were household heads had higher wages. Notice, however, that the coefficients show a decreasing tendency, suggesting a homogenization in earnings between ethnic groups and between household members.

All coefficients for age were positive and for age squared negative. Due to the dimension of the coefficients, the association of wage and age in all years is increasing for young individuals, assumes a maximum respectively at 46, 47, 51, 53 and 55, and decreases afterwards. Notice that the maximum is obtained at higher ages at the end of the period, suggesting an increase in the importance given to labor market experience.

Moreover, those who were employers, formal workers or public workers also earned more than informal workers. The coefficient for the self-employed, for which we did not have any prior expectation, was also positive, but small at the end of the period. As already anticipated, this group is highly heterogeneous, but means that individuals earn a similar wage to informal workers. 
Those who lived in urban and metropolitan areas had higher wages. For macroregions, the coefficients were mostly negative, as expected, indicating that those who lived in the Southeast region had higher wages. The exceptions are the coefficients for the Central-West region, which were negative in 1992 and 1997 and positive afterwards. This indicates that the region was closer to the North and Northeast regions in socioeconomic terms in the beginning of the period, developed at a quicker pace than others, and now resembles the more developed parts of Brazil.

All coefficients for education were positive and increasing in magnitude with educational level, indicating, not surprisingly, that higher levels of education resulted in higher earnings. However, notice that the coefficients for a specific educational level were roughly stable between 1992 and 2002 and diminished after the latter year, suggesting that the premium for education recently decreased in Brazil. Similarly, Trostel, Walker and Woolley (2002) used an OLS model to analyze the trends in returns to education in many countries. They concluded that the returns to schooling did not increase significantly in most countries and decreased in some.

These findings described so far are commonly observed in Mincerian models, and we do not further discuss them. The focus here, however, is study of the male coefficients. In Table 4, they were all positive. That is, after controlling for all the other variables, males had higher hourlywages than females. What about the convergence between the sexes anticipated in sections 1 and 2?

Let's have a closer look at these coefficients, as shown in Figure 10. This figure plots the values for the five coefficients of the above models, which are around the upper line. Clearly, differences between genders decreased: that is, after controlling for the variables in the model, gender wage gaps decreased; however, they are still quite sizable.

Having in mind the brief discussion presented in Table 1, we excluded the education variable from our models, relaxing the effects of allocation of individuals in different educational levels in the labor market. Thus, we are focusing on individuals who are similar in everything except educational levels. These results are also shown in Figure 10, grouped around the lower straight line. The results suggest a greater convergence between sexes, in part because of greater human capital levels, as observed by other authors (Miki; Yuval, 2011). 
Table 4 Results for the Mincerian models by year

\begin{tabular}{|c|c|c|c|c|c|c|}
\hline & \multirow{2}{*}{ Variables } & \multicolumn{5}{|r|}{ Models } \\
\hline & & 1992 & 1997 & 2002 & 2007 & 2012 \\
\hline & Constant & -0.675 & -0.558 & -0.523 & -0.278 & 0.165 \\
\hline \multirow{4}{*}{ 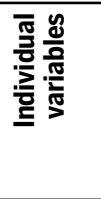 } & Male & 0.358 & 0.318 & 0.281 & 0.264 & 0.279 \\
\hline & White & 0.164 & 0.179 & 0.151 & 0.137 & 0.134 \\
\hline & Age & 0.0441 & 0.0463 & 0.0420 & 0.0400 & 0.0298 \\
\hline & Age squared & -0.000477 & -0.000488 & -0.000412 & -0.000374 & -0.000270 \\
\hline \multirow{4}{*}{ 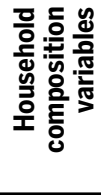 } & Household head & Ref. & Ref. & Ref. & Ref. & Ref. \\
\hline & Spouse & -0.0225 & -0.0184 & -0.0281 & -0.0305 & -0.0175 \\
\hline & Son/Daughter & -0.229 & -0.239 & -0.233 & -0.185 & -0.172 \\
\hline & Others & -0.206 & -0.187 & -0.173 & -0.136 & -0.118 \\
\hline \multirow{5}{*}{ 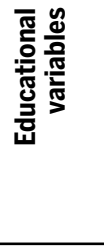 } & 0 to 3 & Ref. & Ref. & Ref. & Ref. & Ref. \\
\hline & 4 to 7 & 0.286 & 0.292 & 0.272 & 0.237 & 0.209 \\
\hline & 8 to 10 & 0.565 & 0.548 & 0.468 & 0.409 & 0.349 \\
\hline & 11 & 0.889 & 0.884 & 0.772 & 0.646 & 0.531 \\
\hline & 12 and over & 1.433 & 1.521 & 1.513 & 1.317 & 1.136 \\
\hline \multirow{5}{*}{ 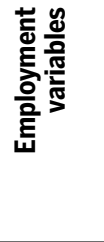 } & Informal & Ref. & Ref. & Ref. & Ref. & Ref. \\
\hline & Formal & 0.460 & 0.220 & 0.210 & 0.189 & 0.133 \\
\hline & Public & 0.500 & 0.350 & 0.462 & 0.473 & 0.442 \\
\hline & Self-employed & 0.264 & 0.155 & 0.0814 & 0.0865 & 0.0721 \\
\hline & Employer & 0.853 & 0.831 & 0.770 & 0.758 & 0.702 \\
\hline \multirow{9}{*}{ 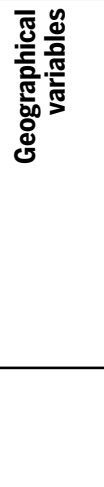 } & Urban & 0.289 & 0.331 & 0.274 & 0.203 & 0.255 \\
\hline & $\begin{array}{l}\text { Metropolitan } \\
\text { area }\end{array}$ & 0.201 & 0.242 & 0.183 & 0.144 & 0.151 \\
\hline & Southeast & Ref. & Ref. & Ref. & Ref. & Ref. \\
\hline & North & -0.102 & -0.121 & -0.0876 & -0.0343 & -0.0953 \\
\hline & Northeast & -0.368 & -0.405 & -0.359 & -0.344 & -0.308 \\
\hline & South & -0.0522 & -0.0850 & -0.0489 & -0.0147 & -0.0118 \\
\hline & Central-West & -0.0393 & -0.0408 & 0.0240 & 0.0603 & 0.0796 \\
\hline & $\begin{array}{l}\text { Number of } \\
\text { observations }\end{array}$ & 102096 & 116126 & 136907 & 152764 & 145050 \\
\hline & R2 & 0.494 & 0.516 & 0.505 & 0.441 & 0.381 \\
\hline
\end{tabular}

Source: PNAD 1992, 1997, 2002, 2007 and 2012

Note: For all coefficients: $p<0.05$.

The regressions above were done for periods. Notice that, for the same period, different cohorts of men and women had different labor market op- 
portunities in a life course perspective, as they had encountered different realities when they started work, and these differences continued to affect them throughout their working lives. Below we show similar Mincerian models with cohorts separated.

Figure 10 Male coefficient in different years with and without control for education

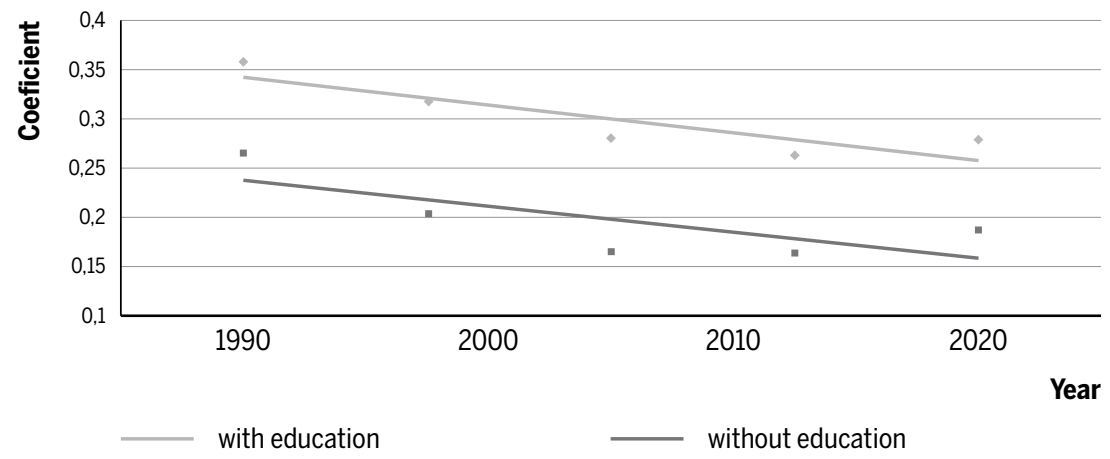

Source: PNAD 1992, 1997, 2002, 2007 and 2012

Due to the increased propensity for retirement of older individuals, we selected the cohorts for which we have data from all five PNADs, the same cohorts shownin figures 6 and 9 . Notice that we are also avoiding the problems of introducing only very young individuals in a particular cohort. It is well known that gender gaps tend to increase when cohorts are in their twenties, and that differences decrease thereafter (Blau; Kahn, 2000).

We focused our attention on the male coefficient, which were all positive and significant, as shown in Figure 11. Similarly to the previous figure, this figure shows the coefficients for the male dummy with and without controlling for educational level, respectively in the upper and lower curve. Notice that the gender gaps for younger cohorts are smaller, suggesting a convergence in wages between the sexes, especially in the analysis which does not control for educational level. Notice, however, that the youngest women we included in the analysis were aged 40 to 44 years old in 2012 . That is, they were still negatively affected by the problems faced by women entering the labor market in earlier periods. We did not estimate the coefficients for younger cohorts, as we do not have complete data in all periods, but we expect even smaller gaps in future studies. 
Figure 11 Male coefficient for different cohorts with and without control for education

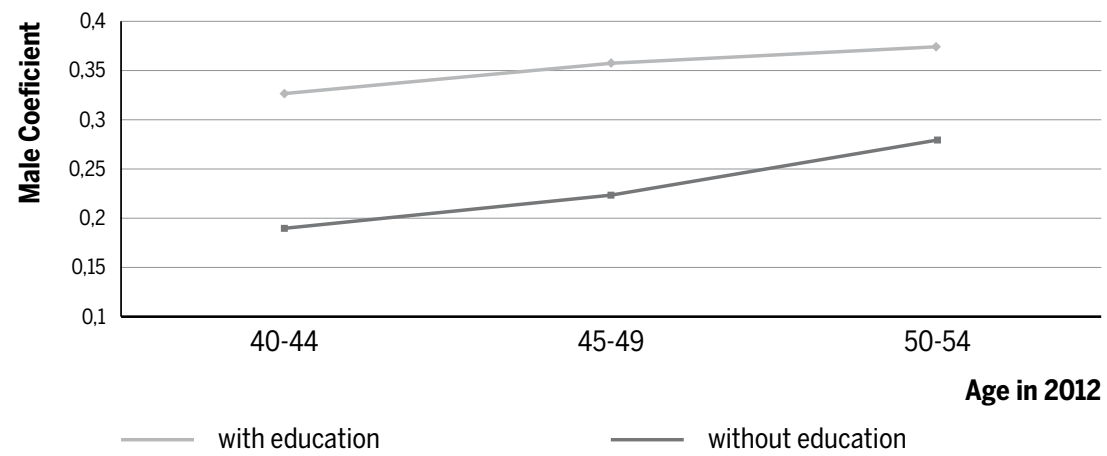

Source: PNAD 1992, 1997, 2002, 2007 and 2012

Mincerian models like those used here do have some limitations. For a methodological discussion of how to estimate the returns of education using other methods see Resende and Wyllie (2006), Sachsida, Loureiro and Mendonça (2004), Trostel, Walker and Woolley (2002) and Weichselbaumer and Winter-Ebmer (2003). Given the objectives of this paper, and in order to partially overcome these limitations, we used hierarchical models based on the APC approach, which are presented below.

\subsection{Hierarchical models and the APC approach}

This second group of models complements the previously presented Mincerian models estimated by OLS. We applied different empirical strategies in order to observe the differences between male and female wages from different perspectives. Given the results of the descriptive section and of the previous econometric models, we decided to apply the models for each cohort separately.

Initially, we applied the model presented in the methodological section. Then we relaxed the analysis, dropping some controls, as we had done with the previous models. Again, the objective is to study gender wage gaps from the traditional perspective and then without controlling for education level and labor market segregation.

Again, the focuses of the analysis are the coefficients for the male dummy, and we restrict our presentation to them. Table 5 presents the results 
for three different models for the same cohorts already discussed. Moreover, we included two younger cohorts in order to observe very recent labor market features. Notice that we are not avoiding the problems of introducing only very young individuals in a particular cohort, as we did in the previous models. Gender gaps tend to increase when cohorts are in their twenties, and then differences decrease (Blau; Kahn, 2000). In general, the gender gap for workloads between men and women increased during the workers' twenties and decreased afterwards, which might explain part of the divergence between sexes in wages for early career (Manning; Swaffield, 2008).

Notice that all coefficients in model 1 were positive and significant, indicating that for all cohorts, after controlling for period, individual, employment, geographical and educational variables, that is, a standard analysis, there were significant gender wage gaps in favor of men. Besides, the coefficients were quite similar for all cohorts, indicating stability in the unexplained part of gender wage gaps. It should be emphasized that the results described by this model clearly indicate that men and women in similar occupations received different wages, indicating a persistent unexplained factor in labor market outcomes which favors men. Besides, as the coefficient was positive for all cohorts, young women are still entering the labor market with lower wages than similar men, but they are expected to catch up at least partially as they age.

The next model drops educational controls. All the coefficients decreased in magnitude, but again all of them were positive, significant and similar. From this perspective, overall gender wage gaps are smaller because women are more educated than men are.

Model 3 drops the employment and geographical variables from the controls. The Brazilian labor market is becoming less segregated, and this might enhance females' wages vis-à-vismales'. Moreover, women tend to be more urbanized than men are. Therefore, if you compare male and female peasants, the former will have higher average earnings. Nevertheless, if a larger proportion of females migrate to urban areas, wage differences will possibly growsmaller or even be reversed, as comparisons will be between urban females and rural males. The model shows that the coefficients were non-significant or positive with smaller magnitude. That is, women's endowments positively influence wages relative to men.

Although women earn less than men with similar occupational status, place of residence and educational attainment, women's endowments par- 
tially or totally compensate for this unexplained advantage tomen. Model 1 shows that there are significant unexplained differences between the sexes in the labor market. However, the other models, showing that women have more favorable endowments and that females are increasingly occupying higher-wage jobs, suggest that in less controlled analysis differences are smaller or non-significant. However, it should be clear that comparisons are not for similar individuals, as I dropped some controls.

Thus, women are promoting a more dynamic convergence in the labor market because of their endowments, indicating a movement from situation 1 to situation 3 in Table 1. Future analysis will tell whether we will move to a time 4 situation. Given that women are becoming more and more present in the labor market and that gaps favoring men are shrinking, it is not unreasonable to consider such a change probable.

Table 5 Hierarchical models and the APC approach: male coefficient for each cohort

\begin{tabular}{lrrr}
\hline Cohort age in 2012 & Model 1 & Model 2 & Model 3 \\
\hline $\mathbf{5 0}$ to $\mathbf{5 4}$ & $0.19^{* *}$ & $0.16^{* *}$ & 0.002 \\
\hline $\mathbf{4 5}$ to $\mathbf{4 9}$ & $0.20^{* *}$ & $0.16^{* *}$ & 0.013 \\
\hline $\mathbf{4 0}$ to $\mathbf{4 4}$ & $0.25^{* *}$ & $0.19^{* *}$ & $0.064^{* *}$ \\
\hline $\mathbf{3 5}$ to $\mathbf{3 9}$ & $0.25^{* *}$ & $0.16^{* *}$ & 0.047 \\
\hline $\mathbf{3 0}$ to $\mathbf{3 4}$ & $0.26^{* *}$ & $0.17^{* *}$ & $0.092^{* *}$ \\
\hline & Controls & & \\
\hline Period variables & Yes & Yes & Yes \\
\hline Individual variables & Yes & Yes & Yes \\
\hline Employment variables & Yes & Yes & No \\
\hline Geographical variables & Yes & Yes & No \\
\hline Educational variables & Yes & No & No \\
\hline
\end{tabular}

Note: * significant at 10\%. ${ }^{* *}$ significant at $5 \%$.

Our final analysis examined the data grouped by cohort and schooling level, as many occupations in the service sector, which has absorbed women better than other sectors relative to men, tend to be occupied by diverse levels of educational attainment. The objective is to observe whether gender wage gaps converge differently for different educational levels.

Table 6 shows the results for the male dummy for two different models for each of the 25 categories of cohort $x$ schooling level. The first model includes all controls, that is, comparisons are made with similar individuals, 
while the second drops the controls for employment type and geography, and hence men and women are not similar in these aspects.

Notice that for levels of education lower than high school, which are from 0 to 10 years of formal education, the coefficients are mostly positive and significant, indicating gender wage gaps favoring men. Coefficients decreased in magnitude when not controlling for employment and geography variables; however, they continued to be significant.

Differently, for individuals with a high school diploma or a higher level of education, most coefficients are non-significant, even including all controls, suggesting similar wages for both genders for more qualified individuals when the study is done by cohort and educational level. Leone and Baltar (2006) also analyzed gender wage gaps for individuals with higher education in Brazil in the 1990s. They observed that men had greater wages and, as we have, they observed a convergence in values for the different sexes.

Based on the glass ceiling literature (Albrecht; Bjorklund; Vroman, 2001; Arulampalam; Booth; Bryan, 2007; Rica; Dolado; Llorens, 2008), this convergence between sexes observed for higher educational level might not be observed for income quantiles at the very end of the distribution.

Table 6 Hierarchical models and the APC approach: male coefficient for each cohort and schooling level

\begin{tabular}{|c|c|c|c|c|c|}
\hline \multirow{2}{*}{$\begin{array}{l}\text { Cohort age } \\
\text { in } 2012\end{array}$} & \multicolumn{5}{|c|}{ Schooling level } \\
\hline & 0 to 3 & 4 to 7 & 8 to 10 & 11 & 12 and above \\
\hline & \multicolumn{5}{|c|}{ Controls: Period, individual, employment type and geographical variables } \\
\hline 50 to 54 & $0.17^{* *}$ & $0.22^{* *}$ & 0.18 & 0.20 & 0.38 \\
\hline 45 to 49 & $0.26 * *$ & $0.18^{* *}$ & $0.18^{*}$ & 0.19 & -0.01 \\
\hline 40 to 44 & $0.31^{* *}$ & $0.29 * *$ & $0.16^{*}$ & 0.17 & -0.042 \\
\hline 35 to 39 & $0.31^{* *}$ & $0.24^{* *}$ & $0.21^{* *}$ & $0.18^{*}$ & 0.013 \\
\hline \multirow[t]{2}{*}{30 to 34} & $0.25^{* *}$ & $0.33^{* *}$ & $0.28 * *$ & 0.062 & 0.32 \\
\hline & & & \multicolumn{3}{|c|}{ Controls: Period and individual variables } \\
\hline 50 to 54 & 0.041 & $0.099 *$ & 0.070 & 0.11 & 0.14 \\
\hline 45 to 49 & $0.10^{* *}$ & $0.10^{* *}$ & 0.10 & 0.045 & 0.12 \\
\hline 40 to 44 & $0.19 * *$ & $0.20 * *$ & $0.13^{*}$ & 0.086 & -0.058 \\
\hline 35 to 39 & $0.19 * *$ & $0.17^{* *}$ & $0.16^{* *}$ & 0.13 & -0.00 \\
\hline 30 to 34 & $0.21^{* *}$ & $0.25^{* *}$ & $0.28^{* *}$ & 0.089 & 0.33 \\
\hline
\end{tabular}

Note: ${ }^{*}$ significant at $10 \% .{ }^{* *}$ significant at $5 \%$. 
We end this section by answering the question of whether or not there are a considerable convergence between the sexes in the Brazilian labor market. If we return to Table 1, considering the results of these last two tables, the answer is partially yes. Surely, the Brazilian labor market is evolving from situation 1 to situation 2 and, in some aspects, to situation 3 . We observed that women generally possess better endowments for the labor market; however, although differences are shrinking, a sizable proportion of the wage gaps continues to be unexplained, possibly due to discrimination.

\section{Final commentaries}

The main objective of this paper was to discuss gender wage gaps in the Brazilian labor market using an APC approach. Historically, men have dominated the labor market, as males' participation was greater and gender wage gaps favored men. However, some recent trends might change this perspective, as the labor market is increasingly becoming a women's locus and in many aspects females in Brazil nowadays have better endowments for the labor market than men. Indeed, the empirical analysis showed a convergence in the Brazilian labor market, especially when gender wage gaps and labor market segregation are analyzed conjointly.

This paper described labor market trends between 1992 and 2012 using PNADs. The descriptive section clearly indicated that gaps in the labor market, such as labor market participation, workloads, experience and earnings, are shrinking between sexes. The gap in educational level is increasing, but this gap favors females. These five trends put together clearly indicate a convergence in the Brazilian labor market.

We further analyzed the data with Mincerian wage equations estimated by OLS for different years, and observed a slight tendency toward wage convergence by gender, especially without controls for educational level. Moreover, we also analyzed models by cohort; the results of this analysis were more striking, indicating smaller differences for younger cohorts and a clearer tendency toward convergence.

A second group of hierarchical models based on the APC approach complemented these models. The studies were done separately for each cohort. The main conclusions were that, although women still earn less than men with similar occupational status, place of residence and educa- 
tional attainment, women's endowments for the labor market are better than men's, and partially compensate the unexplained differences. Moreover, differences in earning between sexes for individuals with at least a high school diploma, when controlling for cohort, were non-significant, indicating a gender wage convergence for more qualified people.

This general tendency toward convergence between genders might be even more pronounced if we take into account that a greater negative selection is expected on males' labor market dropout in Brazil vis-à-vis females, as is observed in the U.S. For instance, in the U.S., black males who were high school dropouts decreased their labor market participation from $91 \%$ to $59 \%$ between 1969 and 2004, a much greater decrease than in other population groups. Moreover, this decline may be even underestimated, as many low-qualified black males in the U.S. were in institutions and did not enter the labor market statistics (Juhn; Potter, 2006). In Brazil, many young unqualified males are becoming part of the triple no group: they do not study, do not work and do not look for a job (Camarano; Kanso, 2008). Hence, they do not enter the Brazilian labor market statistics, except for participation.

The labor market dynamics shown in this paper strongly suggests that the Brazilian labor market evolved to a more homogenous situation between the sexes, although still with considerable gaps between men and women. Future analysis will show if Brazil will one day have a homogenous labor market regarding the sexes. Given the growing educational gaps between the sexes in favor of women, and given that unexplained differences in the labor market, including discrimination, tend to decrease as social roles and norms evolve, our educated guess is that this trend is quite probable.

\section{References}

AMATO, P.; ROGERS, S. Do attitudes toward divorce affect marital quality? Journal of Families Issues, v. 20, n. 1, p. 69-86, 1999.

ALBRECHT, J.; BJORKLUND, A.; VROMAN, S. Is there a glass ceiling in Sweden? IZA DP No. 282, 2001.

ARABSHEIBANI, G.; CARNEIRO, F.; HENLEY, A. Gender wage differentials in Brazil: trends over a turbulent era. World Bank policy research working paper, n. 3148, 2003.

ARULAMPALAM, W.; BOOTH, A.; BRYAN, M.Is there a glass ceiling over Europe? Explo- 
ring the gender pay gap across the wage distribution. Industrial and Labor Relations Review, v. 60, n. $2,2007$.

BAILEY, M.; HERSHBEIN, B.; MILLER, A. The opt-in revolution? Contraception and the gender gap in wages. NBER working paper series, n. 17922, 2012.

BARROS, R.; CORSEUIL, C.; SANTOS, D.; FIRPO, S. Inserção no mercado de trabalho: diferenças por sexo e consequências sobre bem-estar. Texto para discussão n. 796, Rio de Janeiro: IPEA, 2001.

BLAU, F.; KAHN, L. Gender differences in pay. NBER working paper, n. 7732, 2000.

BROWN, C.; CORCORAN, M. Sex-based differences in school content and the male/female wage gap. NBER working paper, $n .5580,1996$.

BRUSCHINI, C. Trabalho doméstico: inatividade econômica ou trabalho não-remunerado? Revista Brasileira de Estudos Populacionais, v.23, n.2,p.331-353, 2006.

CAMARANO, A.; KANSO, S. O que estão fazendo os jovens que não estudam, não trabalham e não procuram trabalho? Boletin Mercado de trabalho: conjuntura e análise. Brasília: IPEA, n. 53, p. 37-44 (nota técnica), 2008.

CAMARGO, J.; SERRANO, F. Os dois mercados: homens e mulheres na indústria brasileira. Revista Brasileira de Economia, n.34, 1983.

FERNÁNDEZ, R.; WONG, J. The disappearing gender gap: the impact of divorce, wages, and preferences on education choices and women's work. NBER working paper series, $n$. $17508,2011$.

GARCÍA, J.; HERNÁNDEZ, P.; LÓPEZ-NICOLÁS, A. How wide is the gap? An investigation of gender wage differences using quantile regression. Empirical Economics, v.26, p.149-167, 2001.

GLOMM, G.; JUNG, J.; TRAN, C. Macroeconomic implications of early retirement in the public sector: The case of Brazil. Journal of Economic Dynamics \& Control, v.33, p.777-797, 2009.

GOLGHER, A. Diálogos com o ensino médio 3: O estudante jovem no Brasil e a inserção no mercado de trabalho. Working paper, Cedeplar, $n^{\circ}$ 393, 2010.

HECKMAN, J.; LOCHNER, L.; TODD, P. Fifty years of Mincer earnings regressions. NBER, Working Paper 9732. Cambridge:2003.

JENSEN, R. Do labor market opportunities affect young women's work and family decisions? Experimental evidence from India. The Quarterly Journal of Economics, v.127, p. 753792, 2012.

JUHN, C.; POTTER, S. Changes in Labor Force Participation in the United States. Journal of Economic Perspectives. v.20, n.3, Summer, p.27-46, 2006.

KHAMIS, M. Comparative advantage, segmentation and informal earnings: a marginal treatment effects approach. IZA discussion paper, n. 3916, 2008.

LEME, M.; WAJNMAN, S. Tendências de coorte nos diferenciais de rendimentos por sexo. In: HENRIQUES, R. (Org.). Desigualdade e pobreza no Brasil. Rio de Janeiro: IPEA, 2000.

LEONE, E.; BALTAR, P.Diferenças de rendimento do trabalho de homens e mulheres com educação superior nas metrópoles. Revista brasileira de estudos de população, v.23, n.2, 2006. 
MADALOZZO, R. Occupational segregation and the gender gap in Brazil: an empirical analysis. Economia Aplicada, v.14, n.2, p.147-168, 2010.

MANNING, A.; SWAFFIELD, J. The gender gap in early-career wage growth. The Economic Journal, v.118 (July), p.983-1024, 2008.

MASON, W.; SMITH H. Age-Period-Cohort Analysis and the Study of Deaths from Pulmonary Tuberculosis. In: MASON, W.; FIENBERG, S. (Ed.) Cohort Analysis in Social Research. New York: Springer-Verlag, p.151-228, 1985.

MAUME, D.; SEBASTIAN, R. Gender, nonstandard work schedules, and marital quality. Journal of Family and Economic Issues, v.33, p.477-490, 2012.

MIKI, M.; YUVAL, F. Using education to reduce the wage gap between men and women. The Journal of Socio-Economics, v.40, p.412-416, 2011.

MONTALI, L. Relação família-trabalho: reestruturação produtiva e desemprego. São Paulo Perspec., v.17 n.2, 2003.

NOPO, H. Promoting equality in the country with the largest earnings gaps in the region: Brazil 1996-2006. In:New Century, Old Disparities: Gender and ethnic earnings gaps in Latin America and the Caribbean. Washington D.C.: Inter-American Development Bank and World Bank, 2012a.

NOPO, H.More schooling, lower earnings: women's earnings in Latina America and the Caribbean. In:New Century, Old Disparities: Gender and Ethnic Earnings Gaps in Latin America and the Caribbean. Washington D.C.: Inter-American Development Bank and World Bank, $2012 b$.

POTTER, J.; SCHMERTMANN, C.; ASSUNÇÃO, R.; CAVENAGHI, S. Mapping the Timing, Pace, and Scale of the Fertility Transition in Brazil. Population and Development Review, v. 36, n. 2, p. 283-307, 2010.

OLIVEIRA, A. A segregação ocupacional por sexo no Brasil. 1997. Dissertação (Mestrado em Demografia) - Cedeplar, UFMG, Belo Horizonte, 1997.

QUEIROZ, B. The evolution of retirement in Brazil. In: XV Encontro Nacional de Estudos Populacionais, ABEP, Caxambu - MG, Brazil, 2006.

RESENDE, M.; WYLLIE, R. Retornos para e educação no Brasil: evidências empíricas adicionais. Economia Aplicada, v. 10, n. 3, p. 349-365, 2006.

RICA, S.; DOLADO, J.; LLORENS, V. Ceilings or floors? Gender wage gaps by education in Spain. Journal of Population Economics, v.21, p.751-776, 2008.

RYDER, N. The cohort as a concept in the study of social change. American Sociological Review, v.30, n. 6, p.843-861, 1965.

SACHSIDA, A.; LOUREIRO, P.; MENDONÇA, M. Um estudo sobre retorno em escolaridade no Brasil. Revista Brasileira de Economia, v. 58, n. 2, p. 240-265, 2004.

SALARDI, $P$. The evolution of gender and racial occupational segregation across formal and non-formal labor markets in Brazil, 1987 to 2006. Review of Income and Wealth, 2014.

SILVA, D.; CARVALHO, A.; NERI, M. Diferenciais de salários por raça e gênero no Brasil: Aplicação dos procedimentos de Oaxaca e Heckman em Pesquisas Amostrais Complexas. Economics Working Papers (Ensaios Econômicos da EPGE) No. 638, FGV/EPGE, 2006. 
TROSTEL, P.; WALKER, I.; WOOLLEY, P. Estimates for the economic return to schooling for 28 countries. Labour Economics, v.9, n.1, p.1-16, 2002.

TSANG, L.; HARVEY, C.; DUNCAN, K.; SOMMER, R. The effects of children, dual earner status, sex role traditionalism, and marital structure on marital happiness over time. Journal of Family and Economic Issues, v.24, n.1, p.5-26, 2003.

WAJNMAN, S.; RIOS-NETO, E. Quantas serão as mulheres? Cenários para atividade feminina. In: BALTAR DA ROCHA, M. I. (Org.). Trabalho e gênero: mudanças, permanências, desafios, ABEP, São Paulo, Editora 34, 2000.

WEICHSELBAUMER, D.; WINTER-EBMER, R. A meta-analysis of the international gender wage gap. Working Paper, Department of Economics, Johannes Kepler University of Linz, No. 0311, 2003.

WHINTER, J.; GOLGHER, A. Uma investigação sobre a aplicação de bônus adicional como política de ação afirmativa na Universidade Federal de Minas Gerais (UFMG). Revista Brasileira de Estudos de População, v. 28, p.333-360, 2010.

YANG, Y. Social Inequalities in Happiness in the United States, 1972 to 2004: an age-period-cohort analysis. American Sociological Review, 73, 2008.

YANG, Y. Aging, Cohorts, and Methods. In: BINSTOCK, R.; GEORGE, L. (Ed.). The Handbook of Aging and the Social Sciences. London: Elsevier, p. 17-30, 2011.

YANG, Y.; FU, W.;LAND, K. A methodological comparison of age-period-cohort models: intrinsic estimator and conventional generalized linear models. Sociological Methodology, v. 34, p. 75-110, 2004.

YANG, Y.;LAND, K.Age-Period-Cohort Analysis of Repeated Cross-Section Surveys: Fixed or Random Effects? Sociological Methods and Research, v.36 (special issue), p.297-326, 2008.

YANG, Y.; SCHULHOFER-WOHL, S.; FU, W.; LAND, K. The Intrinsic Estimator for Age-Period-Cohort Analysis: What Is It and How to Use It. American Journal of Sociology, v.113, n. 6, p.1697-1736, 2008.

\section{About the authors}

Samantha Haussmann - samanthahaussmann@cedeplar.ufmg.br

Cedeplar/UFMG, Belo Horizonte, MG.

AndréBraz Golgher - agolgher@cedeplar.ufmg.br

Cedeplar/UFMG, Belo Horizonte, MG.

This paper is part of the project Demographic transition, labor market and spatial concentration of highly skilled individuals in developing countries. The project was sponsored by Fapemig - Universal CSA APQ 01802-13, and CNPq- Universal $\mathrm{N}^{\circ} 474156 / 2013-3$.

(Esse artigo é parte do projeto Transição Demográfica, Mercado de Trabalho e Concentração de Pessoas com Alta Qualificação em Países em Desenvolvimento financiado pela Fapemig - projeto edital Universal CSA APQ 01802-13, e CNPq - Projeto Edital Universal N474156/2013-3).

\section{About the article}

Submission received on November 3, 2014. Approved for publication on April 28, 2016. 